\title{
Endowment as a Fundraising Tool of the Research University
}

\author{
By Alla Stepanova ${ }^{1}$, Iryna Horbas², Oksana Derkach ${ }^{3}$, Tetyana Ovcharenko ${ }^{4}$
}

\begin{abstract}
The article summarizes the arguments within the scientific discussion about the search of alternative sources of research universities funding in the absence of sufficient support from the government. The main objective of the research is to define the possibility of using the endowment as a fundraising tool to attract alternative sources of funding for research universities in Ukraine. The relevance of solving this scientific issue lies in the fact that modern research universities are independent entities, which according to the Bologna Declaration assume the entire load on the future of the state and have to do it at the highest professional level. This can be ensured through a combination of traditional and modern sources of funding. The world experience of successful implementation of the endowment has been presented. The level of knowledge intensity of GDP, which is one of the key indicators that reflects the level of quality of higher education, has been analyzed. The endowment as one of the most effective fundraising tools is poorly developed in Ukraine. This fact has prompted us to research the main provisions of this phenomenon and to define the conditions for its implementation in Ukrainian research-based institutions of higher education by means of the strategic analysis. The conducted SWOT analysis has made it possible to systematize problem areas of the domestic market of educational services in the direction of creating and using the endowment and predicting possible strategies for its development. Since the Research Universities are considered to be the core of creation of intellectual and innovative products and the crucial mover of scientific and technological progress in the country and in the world, they have been chosen as the research object.
\end{abstract}

Keywords: fundraising, endowment, Research University, market of educational services, investment, alternative sources of funding

\section{Introduction}

Examining the market of educational services, the high level of competition caused by the processes of globalization, integration, innovation development and raising of living standards should be noted. That was the main reason for the implementation of various types of reforms, which would ultimately enable institutions of higher education to compete in the national and subsequently international market of educational services. It is difficult to say what type of reforms should be chosen for a quick and effective implementation, but they have to be based on the principles of market-oriented management. At the same time, the current condition of this segment of the Ukrainian

\footnotetext{
|'Ph.D., Associate Professor, Department of Innovative and Investment Management, Taras Shevchenko National University of Kyiv, Ukraine

2Ph.D., Associate Professor Department of Innovative and Investment Management, Taras Shevchenko National University of Kyiv, Ukraine

3Ph.D., Associate Professor, Department of Innovative and Investment Management, Taras Shevchenko National University of Kyiv, Ukraine

${ }^{4}$ Ph.D., Associate Professor, Department of Innovative and Investment Management, Taras Shevchenko National University of Kyiv, Ukraine
} 
economy is worth noting here. The geopolitical and economic situation is not the most favourable for the domestic economy prompting institutions to take active measures. It is the search for the latest instruments for further activity and development of institutions in the market of educational services, that enables practitioners and researchers to consider the endowment as an adjacent instrument for traditional sources of resource mobilization. The adoption of the Law of Ukraine "On Higher Education" (2014) was a stimulus for the development of endowments in Ukraine.

\section{Research Analysis and Problem Definition}

Scientific researches on the role of research universities clearly identify their role in the country's innovative development. Many authoritative researchers such as Geiger, R.L. (1993); Clark, W. (2006); Salmi, J. (2009) note the importance of the development of the institutions that accumulate and increase the intellectual potential and are the formators of the intellectual capital of the nation. The growth and exacerbation of competition in the national and international markets of educational services encourage to promote the activity of research universities and to search the necessary resources. Definitely, the main sponsor of research universities is the state, which aims to promote education and science system integration and technology transfer into production. Considering the fact that higher education provides the society with positional goods (Hirsch, F. (1976)), which grant access to social prestige and income generation, it is the research universities that aim to maximize their position as producers of positional goods (Marginson, S. (2006)), fulfilling an important socio-economic function of ensuring social well being. At the same time, many historical researches related to the study of the evolution of research universities in the US, European countries, Japan, China, etc. (Graham HD, Diamond, N (1997); Atkinson, R. (2007)) evidence the considerable contribution of the research-based universities to the formation and reproduction of human capital assets, the growth of the innovative and technological potential of countries. In the concept of a triple helix university-business-state, well-known American economist G.Itzkowitz (Etzkowitz H., Leydesdorff, L. (2000)) refers to universities as to a key element of national and regional innovation systems along with power and business.

Of course, a proper understanding of what university endowments are and what goals they pursue should be the starting point. Thus, in Asset Management and University Endowments (2009), Ramsebner, Katrin (2009) highlights an exhaustive review of all aspects of university endowments, such as characteristics of university endowments, investment process, endowments managers and compensations, cost policies. The intricate issue of optimal management of university endowment was thoroughly reviewed by Brown K., Garlappi L., Tiu C. (2010). The research reflected the study of the relationship between decision-making on asset allocation and effectiveness of its management.

In his book Pioneering Portfolio Management, Swensen, David F (2000), chief investment director at Yale University highlights an exhaustive list of endowment goals and notes that university endowments enhance autonomy of universities, provide an independent source of revenue, reduce dependence on government funding, student 
tuition fee and student donations, increase financial stability and create a favourable environment for teaching and research, generally enhancing the attractiveness of the university. In addition, according to Swensen, David F, universities have long-term commitments and are looking for long-term funding sources.

In Jiri Knesl's (2013) opinion, universities manage the common sources of income either as endowments or non-endowments. The author tends to believe that universities are risk-prone, which determines their investment behaviour. Based on these assumptions, it is envisaged to create an investment portfolio of alternative assets that produces better results than conventional $60 / 40$ portfolios. It is the conclusion about comparing the effectiveness of the classic $60 / 40$ portfolio with portfolios with different combinations of alternative portfolios in line with current trends among university endowments that is a key point to Jiri Knesl.

The purpose of the article is to find out the possibility of using the endowment as a fundraising instrument to attract alternative sources of financing for research universities in Ukraine.

\section{Methodology}

The following methods are the basis for the research goal achievement: analysis (the main principles of the formation and performance of the endowment have been analysed), synthesis (application aspects of implementation and performance of the endowment have been defined), generalization (the main problems arising in the process of the formation and performance of the endowment have been specified), analytical (recommendations on the development and improvement of the legislative framework in the field of the endowment in Ukraine have been represented).

\section{Results}

Conducting its core business a research university like any other business entity forms its own development strategy that contains various goals and objectives. It is the research strategies and their successful implementation by the world-class universities (for example, Harvard, Oxford, Cambridge, etc.) that have been the foundation of their high competitive status on the international scene for a long time. Describing the "spirit" of the research university well-known modern researcher of higher education Altbach, P.G. (2004) notes that "the core of the research university is its academic staff, which should be devoted to the idea of the impersonal research for the sake of knowledge in the same way as to more practical elements of research and their application in modern society". According to American researcher Lombardi, J. (2001; 2002], research universities generate the highest level of "internal academic quality", using the most effective resources (human resources: teaching, administrative and research staff, students; material, financial and information resources, etc.) as a fuel for their "engines of quality" as a result, multiplying and reproducing their potential (the ability to raise revenues, namely: tuition fees, endowment funds, grants; the ability to monetize the research results by the mediation of patents, licenses, royalties or in the form of targeted state allocations) (Fig. 1). 


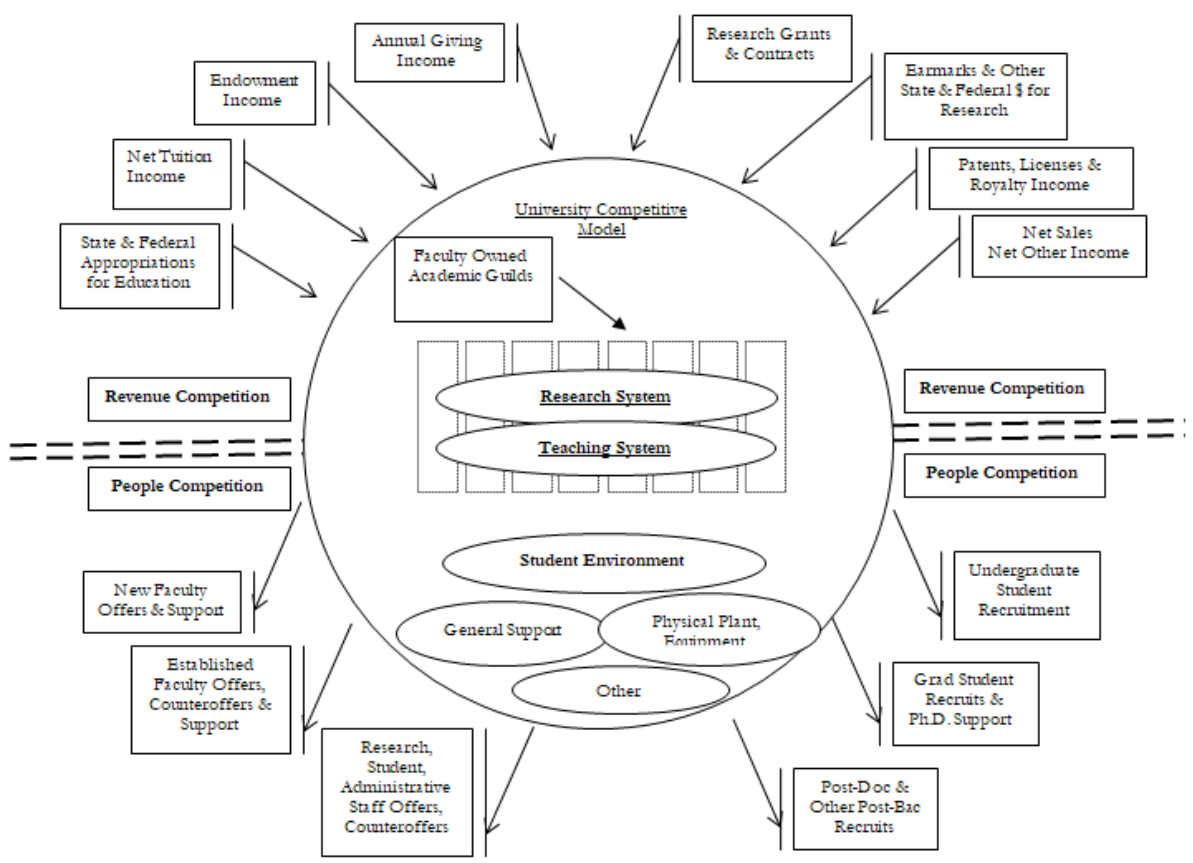

Figure 1. Model of the research university "quality engine"

Source: Lombardi, J., Graig, D., Capaldi, E., Gater, D., Mendonca, S. (2001, pp. 4-6).

Thus, it is possible to develop a high-quality academic and cultural university environment that can generate positive structural socio-economic changes in a regional and national scale.

Currently, there is an urgent need to study domestic research universities and to determine the sources of financing their activities in the global market of educational services.

In order to strengthen Ukraine's position on the international scene and to provide conditions for the innovative development of the economy, it is extremely important to have an adequate level of higher education quality, one of the key indicators of which is the level of knowledge intensity of GDP (Fig. 2).

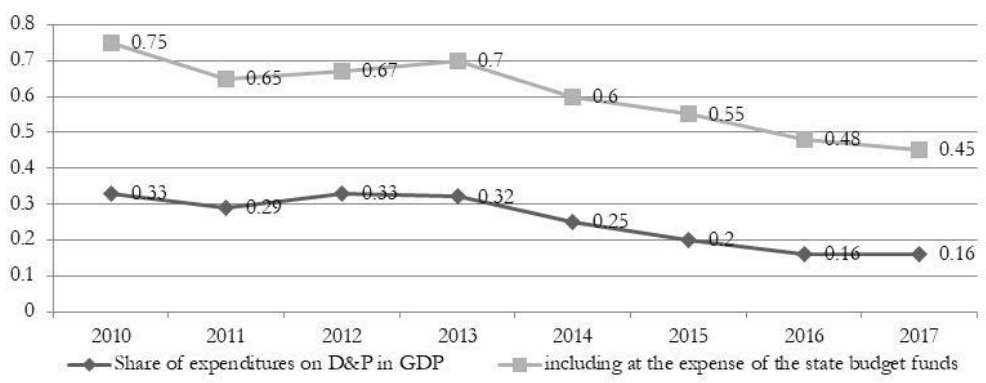

Figure 2. Dynamics of knowledge intensity of GDP of Ukraine, \%

Source: Authors' calculation according to data gathered from the statistical bulletins of Ukraine

(C) 2020 The Authors. Journal Compilation C 2020 European Center of Sustainable Development. 
According to the data of 2016, the share of expenditures on R\&D in GDP of the EU-28 countries averaged $2.03 \%$. It was higher than average in Sweden - 3.25\%, Austria $3.09 \%$, Germany $-2.94 \%$, Denmark - $2.87 \%$, Finland - 2.75\%, Belgium - $2.49 \%$, France $2.25 \%$; smaller - in Macedonia, Latvia, Romania, Cyprus and Malta (from $0.43 \%$ to $0.61 \%)$.

In 2017, the expenditures on R\&D from all sources in Ukraine amounted to UAH 13379.3 million, including UAH 4740.06 million or $35.4 \%$ at the expense of the state budget (Fig. 3).

Having analysed the main tendencies of government funding for education, attention should be given to the alternative sources that have become widespread abroad. It is worthwhile researching such a fundraising tool as the endowment. The main principles of fundraising activities are covered in the Statement of Ethical Principles in Fundraising created by the Institute of Professional Fundraising and include honesty, transparency, integrity, respect and empathy. Using tools of fundraising activity is reasonably necessary for effective work of the public charity institute in the XXI century.

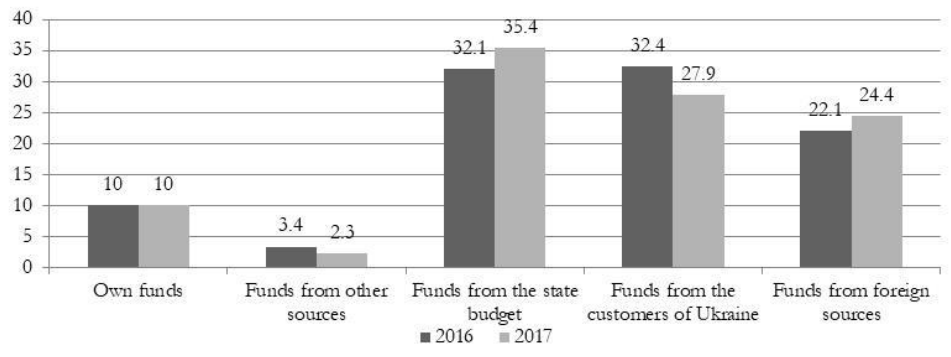

Figure 3. Distribution of R\&D financing by sources, \%.

Source: Authors' calculation according to data gathered from the statistical bulletins of Ukraine

The concept of fundraising is directly related to charity because it is aimed at solving crucial social issues and supporting important programs in social development. The principles of irretrievability, gratuitousness and voluntariness act here. The endowment belongs to the utmost effective modern tools, which is confirmed by the world practice.

In the context of research universities, the endowment is a certain amount of financial and material resources invested in selected objects for profit that is supposed to be used by the university for planned and agreed goals in the future. The provided endowment is absolutely inviolable. In this case, the endowment benefactor has the right to determine the purposes and methods of applying the received profit, which is an objective feature of the endowment concept itself. The United States higher education system is the most striking example of the endowment application. As for the domestic practice of fundraising, there are a number of problems that should be highlighted: low social standards and the level of material provision of the population, the absence of necessary social development programs and a general strategy that borders on social dysfunction of the state in general and provokes the processes of intellectual migration of the population.

It is the endowment that creates the basis for the transition of research universities to a qualitatively new level, where the main consequence is the establishment of the relationship 
"business - science - society". Such a triad of interaction contributes to the coherence of interest and priorities of the development of science and business, the formation and development of human capital, which will ensure the transition of the economy to the innovative level in the long run. The above-mentioned motives for establishing funds' endowments characterize the prospect of raising the level of motivation and awareness of the society, which is a good indication for the future positive perception of innovation changes. In addition, the consequences of the endowments functioning for the needs of education have a direct impact on the innovative development of the national economy, the formation of its innovation paradigm.

The legal basis for the implementation and development of the endowment in Ukraine consists of several key documents. Thus, in the Tax Code of Ukraine Art. 170.7.5. it is indicated that the endowment is an amount of money or securities contributed by a benefactor to a bank or a non-bank financial institution, so that a beneficiary acquires the right to use interests or dividends accrued on the amount of such endowment. At the same time, the beneficiary has no right to spend or to alienate the principal amount of such endowment without the consent of the benefactor. Art. 9 of the Law of Ukraine "On Charitable Activities and Charitable Organizations" defines the assignment of interest and dividends from the management of charitable endowments: providing charitable assistance to beneficiaries identified by benefactors or authorized persons; implementation of charity programs; joint charity activities. It also states that changes in the purposes, procedure and terms of use of the charitable endowment are possible only on the basis of the consent of the benefactor or his successors, as well as by a court decision if the charitable endowment is created on the basis of a will. According to Art. 1 of the Law of Ukraine "On Higher Education" of 01.07.2014 No1556-VII-2 sustainable fund (endowment) of a higher education institution is an amount of funds or value of other property intended for investment or capitalization for a period of not less than 36 months, passive income from which is used by the institution of higher education with the purpose of implementing its statutory activities in the manner determined by the benefactor or his authorized person. Also, Art. 70 of this law states that "institutions of higher education have the right to establish a sustainable fund (endowment) and to dispose the income from its use in accordance with the conditions of the sustainable fund operation as well as to receive property, funds and material assets, in particular buildings, structures, equipment, vehicles from state bodies, bodies of local self-government, legal and natural persons, including as charitable help". It should be noted that the Ukrainian legislation on the endowment regulation is distinct and requires standardization, namely a clear legally established procedure of the formation, implementation and reporting. Today, in Ukraine, the endowment is under development, but there are institutions of higher education mastering these new mechanisms of an alternative source of financing activities.

In modern realities, the following endowments of domestic universities are functioning effectively: the Institute of International Relations Development Fund at Taras Shevchenko National University of Kyiv, the Banking University Development Fund in the Higher Educational Institution of the same name, Kyiv-Mohyla Academy (characterized by the involvement of charitable contributions with elements of the endowment). The presence of insignificant practices in this area leads to more detailed research. 
One of the tools of strategic analysis, namely SWOT-analysis is used for a qualitative reflection of the conditions for the creation and implementation of the endowment in the domestic research-based institutions of higher education. However, taking into account the dynamics of the development of the external and internal environment in the market of educational services, this analysis should be reworked and improved in the long run (Fig. 4).

\section{Strengths (S) \\ 1. Formation of a specific "airbag" enabling using profits from the invested capital management and leaving the capital intact itself.}

2. Wider opportunities for financing of the priority areas of science and

technology (projects, grants, equipment purchase).

3. Transparency for potential benefactors.

4. Positive image.

5. Establishing contacts with the private sector.

6. Tax incentives.

\section{Weaknesses (W)}

1. Lack of clear legal regulation of the sphere of financial and legal relations in the market of educational services. 2. Low public awareness of conditions of the endowment performance.

3. Instability of the macroeconomic situation.

4. Low investment culture of

Ukrainians.

5. Lack of economic incentives for the participants of the educational services market at the state level.

6. Weak development of financial and stock markets.

7. Low level of donor initiatives.

\section{Opportunities (O)}

1. Ensuring the autonomy of funding through the availability of own financial products.

2. Possibility to take leading positions in the market of educational services.

3. Opportunities for investing in the financial and stock markets of the state.

4. Financing of such activities, for which there are not enough resources as a rule. 5. Attraction of highly skilled scientific personnel and development of the latest technologies.

6. Development of the application of the latest technologies.

7. Improving the quality of educational services.

8. Improving the reputation of Ukraine

in the international market of educational services.

\section{S\&O Strategy}

1. Financial autonomy.

2. Positioning the university providing high-quality educational services at the national and international levels.

3. Possibility to occupy a significant part of the domestic market of educational services.

4. Application of the latest technologies.

5. Rapid growth and gaining international recognition.

6. Involvement of highly skilled

international scholars resulting in higher positions in international rankings.

\section{W\&O Strategy}

1. Creation and implementation of the promotion of graduates, lecturers, students, business structures for the endowment formation.

2. Active participation of universities in raising the economic level of the country. 3. Attracting marketing tools to raise public awareness of charity.

4. Optimization of the organizational structure aimed at transparency of universities activity.

\section{T (T)}

1. Incomplete processes of the endowment formation at the legislative level.

2. Possible misuse of the endowment

management (theft, unauthorized use).

3. Insufficient provision of labor resources and highly skilled personnel.

4. Ensuring proper, equal conditions for all participants in the process and market.

5. Insufficient level of competence of the endowment fund board.

6. Unsuccessful choice of an institutional investor for the endowment asset

management.

7. Instability of the political and economic situation, corruption.

\section{S\&T Strategy}

1. Maximum assistance to promote the adoption of all necessary legislative initiatives at the state level.

2. Diversification of assets to ensure a stable return from investment resources. 3. Active promotion of fundraising instruments.

4. Development and implementation of state programs and projects to stimulate industry development.

\section{W\&T Strategy}

1. Formation of transparent and wellbalanced state policy on protection and support of the development of the market of educational services and its subjects.

2. Increasing the level of employees motivation.

3. Promotion of healthy competition in the industry.

4. Expansion of the investment objects list. 5. Involvement of foreign companies with positive and reliable reputation into the university's endowment management. 6. Training of own experts in the endowment management field.

Figure 4. Correlation matrix of SWOT-analysis of the domestic endowment

Source: Author's development 
As a result of the conducted analysis, the strengths and weaknesses of the domestic endowment have been revealed and potential threats and opportunities for its implementation in Ukrainian realities have been highlighted. Thus, enabling the formulation of strategies and directions for the successful implementation of the international practice of using the endowment as one of the fundraising tools.

\section{Conclusions and Perspectives of Further Research}

Summarizing, it is worth of noting that unlike US and European Research Universities, which have been working for more than 200 years, the domestic university sector is under development. The culture of the creation and implementation of endowments in developed countries numbers many generations, which is facilitated by the following factors: a high standard of living; high quality of education; positive attitude of graduates to their educational institutions; transparency of the endowments performance, which is achieved through the operation of laws; purposeful use of the received profit; financial independence. However, Ukraine has all conditions for the expansion and growth of the endowment role in universities. Choosing a "normative" model for the development of research universities through appropriate principles, rules and procedures, modernizing the state strategy and tactics in this area according to the best world standards, Ukraine will be able to contribute to the growth of the competitive potential of the national institution of higher education as a whole. It is also important to note that the updated version of the Law of Ukraine "On Higher Education" has to be systematically aimed at achieving these goals, thus, enabling making real estate and securities contributions. Having a great potential for charity, it is worthwhile to perform highly professional activity explaining the importance of the endowment in the development of universities and involving the population and business structures into the educational space of the country through the endowment.

Further research of the chosen issue is planned to be carried out in the context of the search for political priorities, strategic goals and directions of the state policy of Ukraine in the field of scientific research and education, aimed at creating competitive research universities.

\section{References}

Analytical certificate State of development of science and technology, results of scientific and scientific and technical activities in 2017. Retrieved from https://mon.gov.ua/ua/nauka/nauka/informacijnoanalitichni-materiali/ (referred on 20/10/2018)

Analytical certificate State of development of science and technology, results of scientific and scientific and technical activities in 2016. Retrieved from https://mon.gov.ua/ua/nauka/nauka/informacijnoanalitichni-materiali/ (referred on 20/10/2018)

Atkinson, R. (2007) 'Research Universities: Core of the US Science and Technology System', Research \& Occasional Paper Series: CSHE, May, Retrieved from http://cshe.berkeley.edu/publications/docs/ROPS.RCA.Blanpied.ResUniv.5.07.a.pdf/

Altbach, P.G. (2004) 'The costs and benefits of world-class universities', Academe, vol. 90, no. 1, Retrieved from http://www.aaup.org/AAUP/pubsres/academe/

Altbach, P.G. (2011) 'The Past, Present, and Future of the Research University', in: P.G. Altbach \& J. Salmi (eds), The road to academic excellence: the making of world-class research universities, The World Bank, Washington DC. 
Brown K., Garlappi L., Tiu C. Asset allocation and portfolio performance: Evidence from university endowment funds. Journal of Financial Markets. 2010. Vol. 13. Issue 2. P. 268-294. doi:https://doi.org/10.1016/i.finmar.2009.12.001

Clark, W. (2006) Academic Charisma and the Origins of the Research University, Chicago, The University of Chicago Press.

Etzkowitz, H., Leydesdorff, L. (2000) 'The dynamics of innovation: from National Systems and "Mode 2" to a Triple Helix of university-industry-government relations', Research Policy, vol. 29, no. 2, pp. 109-123.

Geiger, R.L. (1993) Research and Relevant Knowledge: American Research Universities since World War II, Oxford University Press, New York.

Graham, H.D., Diamond, N. (1997) The Rise of American Research Universities: Elites and Challengers in the Postwar Era, JHU Press.

Gross domestic expenditure on R\&D (GERD) \% of GDP. Retrieved from http://ec.europa.eu/eurostat/tgm/refreshTableAction.do?tab $=$ table\&plugin $=1 \& p c o d e=t 20202$ 0\&language $=\mathrm{en} /($ referred on $07 / 01 / 2019)$

Hirsch, F. (1976) Social Limits to Growth, Cambridge MA, Harvard University Press

International Statement of Ethical Principles in Fundraising. Retrieved from http://www.cfre.org/certification/ethics-and-accountability/international-statement-of-ethicalprinciples-in-fundraising/ (referred on 28/10/2018)

Jiri Knesl (2013) Asset Management - University Endowments, Master Thesis - Vienna University of Economics and Business. Retrieved from https://www.professionsfinancieres.com/sites/default/files/docsupload/u213/M\%20Jiri\%20KN ESL.pdf/

Law of Ukraine on charitable activities and charitable organizations No. 5073-VI dated July 5, 2012. Retrieved from http://zakon2.rada.gov.ua/laws/show/5073-17/ (referred on 20/10/2018)

Law of Ukraine on Higher Education No. 1556-VIII 2 dated July 1, 2014. Retrieved from http://zakon1.rada.gov.ua/laws/show/1556-18/(referred on 20/10/2018)

Lombardi, J., Graig, D., Capaldi, E., Gater, D., Mendonca, S. (2001) 'Quality Engines: The American Research University Prototype', in: Quality Engines: The Competitive Context for Research Universities, The Center for Measuring University Performance, An Annual Report from The Lombardi Program on Measuring University Performance. Retrieved from http://mup.asu.edu/research2001.pdf/

Lombardi, J., Graig, D., Capaldi, E., Gater, D., Mendonca, S. (2002) 'University Organization, Governance, and Competitiveness', in: The Top American Research Universities, The Center for Measuring University Performance, An Annual Report from The Lombardi Program on Measuring University Performance. Retrieved from http://mup.asu.edu/research2002.pdf/

Marginson, S. (2006) 'Dynamics of National and Global Competition in Higher Education', Higher Education, vol. 52, no. 1, pp. 1-39. doi: https://doi.org/10.1007/s10734-004-7649-x/

Marginson, S. (2012) 'Emerging countries need world-class universities', University World News, Issue No: 214. Retrieved from http://www.universityworldnews.com/article.php?story $=20120320114704953$ \&query $=$ marginson $/$.

Ramsebner, Katrin (2009) Asset Management and University Endowments, 'Magistra'-Thesis, University of Vienna

Salmi, J. (2009). The challenge of establishing world-class universities. Washington, DC: The World Bank.

Satsik V. (2012). Modern Models of Research Universities: Origins, Development Strategies and Perspectives for Development in Ukraine. Ideology and Politics. 2. 25-39.

Swensen, David F. (2000) Pioneering Portfolio Management, The Free Press, New York, NY.

Tax Code of Ukraine. Retrieved from http://zakon2.rada.gov.ua/laws/show/2755-17/ (referred on 20/10/2018)

The Strategic Plan for University Development for the Period 2018-2025 was approved by the Academic Council of the University on June 25, 2018. Retrieved from http://www.univ.kiev.ua/pdfs/official/Development-strategic-plan.pdf// (referred on $20 / 10 / 2018)$

Vasilkova N.V. (2016). Key factors for the success of universities in the global market for educational services. Economic Bulletin of the National Technical University of Ukraine "Kyiv Polytechnic Institute". 13. 335-341. doi: https://doi.org/10.20535/2307-5651.13.2016.80564/ 